\title{
A stochastic frontier approach to modelling financial constraints in firms: An application to India
}

\author{
Sumon Kumar Bhaumik ${ }^{\text {a, }}$, Pranab Kumar Das ${ }^{\text {b }}$, Subal C. Kumbhakar ${ }^{\text {a c }}$ \\ ${ }^{a}$ Aston Business School, Aston University, Birmingham B4 7ET, United Kingdom \\ ${ }^{\mathrm{b}}$ Centre for Studies in Social Sciences, Kolkata 700 094, India \\ ${ }^{c}$ Department of Economics, Binghamton University, New York 13850, USA
}

This version: 17 September, 2011

\begin{abstract}
:
We propose the use of stochastic frontier approach to modelling financial constraints of firms. The main advantage of the stochastic frontier approach over the stylised approaches that use pooled OLS or fixed effects panel regression models is that we can not only decide whether or not the average firm is financially constrained, but also estimate a measure of the degree of the constraint for each firm and for each time period, and also the marginal impact of firm characteristics on this measure. We then apply the stochastic frontier approach to a panel of Indian manufacturing firms, for the 1997-2006 period. In our application, we highlight and discuss the aforementioned advantages, while also demonstrating that the stochastic frontier approach generates regression estimates that are consistent with the stylised intuition found in the literature on financial constraint and the wider literature on the Indian credit/capital market.
\end{abstract}

JEL classifications: C51; G31; G32; L21

Keywords: Firm investment; Financial constraint; Stochastic frontier analysis; India

* Corresponding author. Tel.: +44 121 2043038; fax: +44 1212043306

Email addresses: s.bhaumik@aston.ac.uk (S.K. Bhaumik), pkdas@ cssscal.org (P.K. Das), kkar@binghamton.edu (S.C. Kumbhakar) 


\section{Introduction}

In the aftermath of the financial crisis of 2008-09, a debate about the continuing impact of the crisis on the financial constraints of firms continues to rage. The issue of financial constraints has long been examined in the literature. It is argued that in a frictionless world, a firm's decision to invest depends on its Tobin's $q$ (Yoshikawa, 1980), and demand for its output (Abel, 1980). ${ }^{1}$ However, as demonstrated by Stiglitz and Weiss (1981), capital markets are characterised by friction, and the presence of market failure implies that the observed investment decisions of firms are also influenced by the extent of their financial constraint.

Following the research of Fazzari, Hubbard and Petersen (1988), the stylised literature argues that if a firm's investment is significantly dependent on (and positively correlated with) its cash flow, then the firm can be deemed financially constrained. The significance (and positive sign) of the coefficient for the cash flow variable is borne out by a number of empirical studies (e.g., Bond and Meghir, 1994; Kadapakkam, Kumar and Riddick, 1998). ${ }^{2}$

${ }^{1}$ Hayashi (1982) demonstrates that for a price taking firm in both the product and factor markets, with a linear homogeneous technology and linear homogeneous adjustment cost of capital, (generally unobservable) marginal $q$ equals (more readily observable) average $q$. If these assumptions are violated, investment depends on output as well.

${ }^{2}$ It is sometimes argued that a significant coefficient of the cash flow variable does not necessarily indicate presence of a financial constraint. If a firm has the ability to maintain investment in fixed capital by adjusting working capital, the coefficient of the cash flow variable would capture shifts in investment demand. One implication of this line of argument is that reduced form models underestimate the impact of financial constraints on investment (see Fazzari and Petersen, 1993, for details). Some studies, therefore, use cash holding of 
The literature also finds that, in keeping with the banking literature, larger firms that are in a better position to reduce the threat of adverse selection by posting collateral are less financially constrained than smaller firms (Audretsch and Elston, 2002; Beck and DemirgucKunt, 2006). ${ }^{3}$ Other factors that can ameliorate the problems associated with informational asymmetry, such as banking relationships (Shen and Wang, 2005), reduce the sensitivity of investment to cash flows. On the other hand, this sensitivity is increased by firm characteristics such as high leverage (Aivazian, Ge and Qiu, 2005). ${ }^{4}$

In the stylized literature, the sample of firms is generally classified into groups that have differential cost of information, e.g., on the basis of dividend payouts, size and age. The differences in the sensitivity of investment to cash flow for these groups are interpreted as the manifestation of different degrees of financial constraint. The classification criteria are

firms instead of cash flow. However, the use of cash flow in empirical specifications, and the use of its estimated coefficients to draw inferences about financial constraint experienced by firms are stylised in the literature.

${ }^{3}$ Audretsch and Elston (2002) demonstrate that, in Germany, on account of the financial infrastructure to support small firms, it is the medium sized firms that are most credit constrained. But in the United States and the United Kingdom, in keeping with the prediction, the smaller firms are more credit constrained.

${ }^{4}$ The earlier literature focuses almost entirely on financial constraints in developed countries. More recently, however, researchers have focused on developing countries and emerging markets, specifically on the impact of financial liberalization on financial constraints in these countries. See, for example, Guncavdi, Bleaney and McKay (1998), Gelos and Werner (2002), and Wang (2003). 
largely ad hoc, and arguably can lead to erroneous conclusions (Kaplan and Zingales, 1997; Laeven, 2003).

In this paper, we propose an alternative approach to empirically modelling financial constraints - using stochastic frontiers - which improves over the aforementioned stylized approach in three different ways. First, rather than inferring the existence of financial constraint from the sign and significance of the cash flow variable, the stochastic frontier approach enables us to estimate a measure of financial constraint for each individual firm and at each point in time. Since our outcome variable (desired or optimum investment) has a natural maximum which is unobserved, the observed value of the outcome variable will not exceed its desired (maximum) value. We estimate the unobserved maximum value (desired investment) econometrically using actual data on the outcome variable and some covariates, and thereby compute the shortfall of investment from its desired value. This shortfall is then attributed to financial constraint. ${ }^{5}$ Second, we are able to directly estimate the marginal impact of firm characteristics such as size and leverage on financial constraint (and therefore on desired investment), without inferring the different degrees of financial constraint on different types of firms by splitting the sample into different groups on the basis of some $a d$ hoc criteria, and thereafter estimating the different degrees of responsiveness of the investment of the average firm in each of these groups to cash flows. Finally, we are able to estimate this marginal impact at different levels of the (continuous measures) of firm

\footnotetext{
${ }^{5}$ Alternatively, this 'shortfall' can be viewed as a measure of investment efficiency that is bounded between 0 and 1 , so that the investment frontier is attained when the efficiency is 1 . This investment efficiency score tells us the degree of credit constraint for each firm and for every year. Importantly, this measure reflects the impact of all the factors (observed as well as unobserved) that inhibit attaining the investment frontier, ceteris paribus.
} 
characteristics, thereby developing a better understanding of, for example, whether a firm should be of a minimum size or whether it should have a minimum level of cash flow in order for it to significantly reduce the extent of financial constraint.

We use the stochastic frontier approach to estimate measures of financial constraints among a panel of Indian manufacturing firms, for the 1997-2006 period, and identify firm characteristics that explain variations in these measures across firms and over time. Our results suggest that, in keeping with the existing literature in firm-level investments, cash flows and assets of firms alleviate financial constraints. The degree of financial constraint is higher for highly leveraged firms. These results are consistent with the literature that suggests that there is significant threat of adverse selection in the Indian credit market, sometimes contributing to market failure. We also find that business groups alleviate credit constraints for member firms, but their ability to do so has declined over time. Further, this decline was not offset by changes in other characteristics of business group affiliated firms; the difference in the median investment efficiency of business group affiliated and unaffiliated firms increased between 1997 and 2006.

The rest of the paper is organised as follows: In Section 2, we briefly review the stylized empirical approach used to infer presence of financial constraints, and discuss how the stochastic frontier approach significantly improves on this stylized approach. In Section 3, we discuss the data, and the empirical strategy. The regression results, and the specific insights derived from using the stochastic frontier approach, are discussed in Section 4. Finally, Section 5 concludes.

\section{Measuring and explaining financial constraints}




\subsection{The stylized approach}

To recapitulate, the literature on investment decisions of firms builds on the work of Fazzari, Hubbard and Petersen (1988), who use Value Line data for 422 large U.S. manufacturing firms over the 1970-84 period. If a value maximizing firm is not financially constrained, its investment decisions depend only on its future prospect, which is captured by Tobin's $q,{ }^{6}$ and perhaps also by its current and past sales. However, if the firm is finance constrained, its investment is also affected by cash flow that is a proxy for internal resources. In the tradition of the literature we characterise the regression model as follows:

$$
\frac{I_{i t}}{K_{i, t-1}}=f\left(\frac{X_{i t}}{K_{i, t-1}}\right)+g\left(\frac{C F_{i t}}{K_{i, t-1}}\right)+\varepsilon_{i t}
$$

where $I$ is investment, $X$ is vector of variables that captures investment opportunities, $C F$ is cash flow, $K$ is capital, and $\varepsilon$ is the independently and identically distributed (i.i.d.) noise term. In light of our earlier discussion, it is obvious that the components of vector $X$ are Tobin's $q$ and present and lagged values of sales. In the literature, variants of this model have been estimated using both pooled (ordinary least squares) regression (Lang, Ofek and Stulz, 1996) and fixed effects panel regression models (Aivazian, Ge and Qiu, 2005).

Equation [1] is generally extended, as required, to examine the impact of factors over and above cash flow that can capture frictions in the capital market on investment levels. Furthermore, where panel data are used, firm and time-effects are added to control for possible firm- and time-heterogeneity in the intercept. For example, Aivazian, Ge and Qiu

\footnotetext{
${ }^{6}$ For a discussion of the optimisation problem of a value-maximising firm that underpins this specification, see Hubbard (1998).
} 
(2005) examine the impact of leverage on firm investment in Canada using the following regression model:

$$
\frac{I_{i t}}{K_{i, t-1}}=\alpha+\beta\left(\frac{C F_{i t}}{K_{i, t-1}}\right)+\delta \ln Q_{i, t-1}+\phi\left(\frac{S A L E_{i, t-1}}{K_{i, t-1}}\right)+\rho L E V E R A G E_{i, t-1}+\theta_{t}+\mu_{i}+\varepsilon_{i t}
$$

where $\theta$ and $\mu$ capture time and firm fixed effects, and $\varepsilon$ is the i.i.d error term. As in the case of [1], if the cash flow and leverage coefficients in above regressions are found to be statistically significant, one might argue that firms are finance constrained.

In much of the literature, the sample of firms is classified into groups that have differential cost of information, and hence different likelihoods of being financially constrained, on the basis of some criterion. The differences in sensitivity of investment to internal resources (i.e., cash flows) for these groups capture the differences in the extent of credit constraint. The Fazzari, Hubbard and Petersen (1988) paper classify firms on the basis of their dividend payouts, while other studies use firm characteristics such as size and age. While the basis for the chosen criteria are plausible, it is nevertheless ad hoc, especially when the criteria are potentially time varying. Kaplan and Zingales (1997) show that the cash flow sensitivity to investment could lead to erroneous conclusion when firms are classified into groups of high or low costs of information by dividend pay-out or any other criterion. As discussed in Laeven (2003), a priori classification of firms into groups using other criteria might lead to erroneous conclusion as well.

\subsection{The stochastic frontier approach}

The stochastic frontier approach is an econometric technique that is primarily constructed to estimate the underlying production technology along with technical inefficiency for 
individual producers (Kumbhakar and Lovell, 2000). The unique feature of the stochastic frontier model is that the error term is the sum of a one-sided (i.e., non-negative) technical inefficiency term and a two-sided noise term. In principle, the stochastic frontier tool can be used in a variety of cases where the one-sided technical efficiency can be viewed as deviation of the outcome variable from its (desirable) maximum/minimum value (which is unobserved). For example, observed wage is likely to be less than the maximum the employers were willing to pay (which is unobserved). Similarly, the (observed) selling price of a house is likely to be more than the (unobserved) minimum that the seller was willing to accept. In our case, the observed amount of investment by a firm is always less than (or equal to) the unobserved desired level of investment, on account of factors that increase firmspecific risk or informational cost. Hence, just as in the example about wages the one-sided technical efficiency term reflects the informational constraint that prevents the employees from extracting the full wage that the employer was, in principle, willing to pay, so also in our context the one-sided technical efficiency term can be labelled as the effect of financial constraint on investment. This enables us to model financial constraints of firms on investment using the stochastic frontier approach which, as we discuss below more formally, provides a better way of testing the presence of constraints in the investment function and examining the impact of the constraining variables on investment.

As discussed above, in the stylised literature that builds on the pioneering work of Fazzari, Hubbard and Petersen (1988), a firm's investment decisions depend only on its future prospect, which is captured by Tobin's $q$, and perhaps also by its current and past sales (the components of vector $X$ in equation 1). If other firm characteristics such as cash flow have an impact on these investment decisions, the firm is believed to be financially constrained. In 
other words, in the absence of capital market imperfections and financial constraints, Tobin's $q$ and current and past sales are sufficient to characterise the investment decisions of the firm.

In keeping with this, Wang (2003) argues that in the absence of agency conflicts and capital market imperfections a firm's investment decision can be defined as follows:

$\ln \left(\frac{I_{i t}}{K_{i, t-1}}\right)^{S F}=\alpha+\beta \ln Q_{i, t}+\gamma \ln \left(\frac{S A L E_{i, t}}{K_{i, t-1}}\right)+\delta \ln \left(\frac{S A L E_{i, t-1}}{K_{i, t-2}}\right)+\theta_{t}+\mu_{i}+\varepsilon_{i t}$

where $\theta, \mu$ and $\varepsilon$ have the same interpretation as above. This regression model, therefore, defines the efficient investment function (frontier). In the presence of financing constraints, the observed investment-to-capital ratio is less than the efficient (optimal) investment-tocapital ratio in [3]. Thus, the difference between this efficient investment-to-capital ratio and the observed investment-to-capital ratio is attributed to financing constraint. This difference can be represented by a non-negative term $u$. More specifically, we write the observed investment-to-capital ratio as:

$\left(\frac{I_{i t}}{K_{i, t-1}}\right)=\left(\frac{I_{i t}}{K_{i, t-1}}\right)^{S F} \exp \left(-u_{\mathrm{it}}\right) \quad \Rightarrow \quad \ln \left(\frac{I_{i t}}{K_{i, t-1}}\right)=\ln \left(\frac{I_{i t}}{K_{i, t-1}}\right)^{S F}-u_{i t}$

Models [3] and [4] together define the stochastic frontier formulation of the investment function, and can be estimated using the distributional assumptions on $u$ and $\varepsilon$ that were discussed earlier. It is evident that the stochastic frontier approach gives us not only the estimates of the parameters of the investment function but observation-specific estimates of the one-sided investment efficiency term $u$ as well, and therein lies the key to the application of stochastic frontier approach to the literature on firm-level financial constraints. Note that the first part of [4] shows that $I_{i t} / I_{i t}^{S F}=\exp \left(-u_{i t}\right)$, given $K_{i, t-1}$. Therefore, $I_{i t} / I_{i t}^{S F}$ can be viewed as investment efficiency which is bounded between 0 and 1 . Thus, for example, an efficiency score of 0.8 indicates that the firm's investment is at 80 percent of its desired level. 
Alternatively, $u$ times 100 can be viewed as the percentage shortfall of investment from its desired (frontier) level due to the presence of financial constraints. Thus, $u$ can be labelled as investment inefficiency (which parallels the definition of technical inefficiency in production function models). It measures shortfall of investment from its desired level (just like technical inefficiency which measures output shortfall, in percentage terms) manifesting the presence of financial constraints.

The first (and perhaps the main) advantage of the stochastic frontier approach, therefore, is that the estimated (non-negative) values of $u$ can tell us not only whether a firm is financially constrained, but also the degree (or severity) of this constraint. The higher the value of $u$ greater is the impact of constraints on investment. Thus, in the present case, the frontier represents the desired investment function which is unobserved and the $u$ term represents a firm's inability to attain the investment frontier, ceteris paribus, due to the presence of financing constraints. Aside from the ease of interpretation, the investment efficiency score has the advantage that it captures the combined impact of all the constraining variables on the extent of credit constraint. By contrast, alternative methodologies such as OLS or fixed effects panel regression models captures only the marginal impact of individual firm characteristics $(Z)$ on investment of the average firm, and hence do not tell us whether or not an individual firm is credit constrained overall, and if so by how much. ${ }^{7}$ With the stochastic ${ }^{7}$ The intuition for this observation is clear: high leverage, for example, may increase the extent of a firm's financial constraint on its own, but the firm might be able to offset this disadvantage by having its loans de facto underwritten by a wider business group, thereby reducing the overall degree of its credit constraint. The technical explanation is as follows: In models such as [1] and [2] the difference between the expected values of $\ln \left(I_{i t} / K_{i, t-1}\right)$ with and without the $\mathrm{Z}$ variables might not be negative. A negative value for $E\left(\left.\ln \left(I_{i t} / K_{i, t-1}\right)\right|_{\mathrm{Z}=0}\right)-$ 
frontier approach, therefore, it is possible to examine distributions of the extent of financial constraints of the firms from the efficiency scores, and compare distributions of financial constraints across firm types and over time. Importantly, adoption of the stochastic frontier approach eliminates the requirement to use any ad hoc criteria to split the sample, to understand the different degrees of financial constraint of different types of firms.

Another advantage of the stochastic frontier approach is that we can directly estimate the impact of firm characteristics $(Z)$ such as size and leverage on the degree of financial constraint, rather than estimate the impact of these characteristics on investment of the average firm and infer from these estimates whether or not they contribute to financial constraint (for example, in [2]). This can be done by extending the basic model proposed above to accommodate the $\mathrm{Z}$ variables. As discussed earlier, in the stylized literature, firm characteristics that impact financial constraint of firms include the logarithm of physical assets (LOGASSET), cash flows $(C F)$, and financial fragility that is usually measured using the debt-to-equity ratio ( $L E V E R A G E)$. In certain contexts, financial constraint is also affected by membership of business groups $($ GROUP $),{ }^{8}$ and the impact of business group membership $E\left(\left.\ln \left(I_{i t} / K_{i, t-1}\right)\right|_{\mathrm{Z} \neq 0}\right)$ can be interpreted as percentage reduction in investment due to the presence of credit constraints (proxied by the $\mathrm{Z}$ variables), where $E($.$) is the expectation operator. In$ other words, although one can show that firms are credit constrained from the marginal effects of the $\mathrm{Z}$ variables, it is not possible to quantify the degree of it.

${ }^{8}$ We have already discussed the ways in which cash flow, firm size or assets, and leverage affect financial constraints. The literature also suggests that the impact of capital market failure on investment can be reduced by organisational structures such as business groups. This could be, as in the case of Japan, on account of access to banks that are an integral part of these groups (Hoshi, Kashyap and Scharfstein, 1991). Alternatively, this could be on 
on financial constraint can be time varying. We accommodate these $Z$ variables into the model via the inefficiency term, i.e., we now assume that $u_{i t} \sim N\left(0, \sigma_{u}^{2}\left(Z_{i t}\right)\right), u_{i t} \geq 0$ where $\sigma_{u}\left(Z_{i t}\right)=\exp \left(\gamma^{\prime} Z_{i t}\right)$ and $\gamma^{\prime} Z_{i t}$ is specified as

$$
\begin{gathered}
\gamma^{\prime} Z_{i t}=\varphi\left(\frac{C F_{i t}}{K_{i, t-1}}\right)+\pi L O G A S S E T_{i, t}+\rho L E V E R A G E_{i, t}+\omega G R O U P_{i t} \\
+\sigma\left(\text { GROUP }_{i t} \times \text { TIMETREND }\right)
\end{gathered}
$$

where the exponential specification is used to ensure non-negativity of $\sigma_{u}\left(Z_{i t}\right),{ }^{9}$ and $\gamma$ is the parameter vector associated with these $Z$ variables. Since, in this specification, $E\left(u_{i t}\right)=$ $\sqrt{2 / \pi} \sigma\left(Z_{i t}\right)=\sqrt{2 / \pi} \exp \left(\gamma^{\prime} Z_{i t}\right)$, we can easily find the marginal effect of individual $Z$ variables on investment inefficiency. If a $Z$ variable lowers $u$ (i.e., relaxes the financing constraint), the marginal effect will tell us by what percent investment will increase if a $Z$ variable is increased by one percent.

Indeed, it can be argued that (variations of) the specification used in the OLS and fixed effects panel approaches are a special case of the stochastic frontier model. Consider, for example, the following variation of [1] which includes the $Z$ variables enumerated in [5]:

$$
\begin{gathered}
\ln \left(\frac{I_{i t}}{K_{i, t-1}}\right)=\alpha+\beta \ln Q_{i, t}+\gamma \ln \left(\frac{S A L E_{i, t}}{K_{i, t-1}}\right)+\delta \ln \left(\frac{S A L E_{i, t-1}}{K_{i, t-2}}\right)+\varphi\left(\frac{C F_{i t}}{K_{i, t-1}}\right)+\pi \operatorname{LOGASSET}_{i, t} \\
+\rho L E V E R A G E_{i, t}+\omega G R O U P_{i t}+\sigma\left(\operatorname{GROUP}_{i t} \times \text { TIMETREND }\right)+\theta_{t}+\mu_{i}+\varepsilon_{i t}
\end{gathered}
$$

account of internal capital markets that are generally associated with business groups such as the Korean chaebols (Shin and Park, 1999).

${ }^{9}$ TIMETREND is a variable that has the value one for the first year of the sample period and increases by one for each subsequent year in the sample period. The interaction term involving the group membership dummy and the time trend variable captures the changing impact of business group membership on a firm's financial constraint over time. 
Next, consider the stochastic formulation of the baseline equation:

$$
\ln \left(\frac{I_{i t}}{K_{i, t-1}}\right)=\alpha+\beta \ln Q_{i, t}+\gamma \ln \left(\frac{S A L E_{i, t}}{K_{i, t-1}}\right)+\delta \ln \left(\frac{S A L E_{i, t-1}}{K_{i, t-2}}\right)+\theta_{t}+\mu_{i}+\varepsilon_{i t}-u_{i t}
$$

If we denote $v_{i t}=\varepsilon_{i t}-u_{i t}$, it is clear that $v_{i t}$ will have a non-zero mean because $u_{i t}$ is nonnegative, and this poses a problem in using OLS (which will assume zero mean error). This non-zero mean problem can be avoided by rewriting $v_{i t}$ as $v_{i t}=\varepsilon_{i t}-\left(u_{i t}-E\left(u_{i t}\right)\right)-$ $E\left(u_{i t}\right) \equiv \varepsilon_{i t}^{*}-E\left(u_{i t}\right)$ where $E\left(\varepsilon_{i t}^{*}\right)=0$ by construction. We then get an error term that has a zero mean but need to account for the extra term $-E\left(u_{i t}\right)$ in the regression. If we assume that

$$
\begin{gathered}
-E\left(u_{i t}\right)=\varphi\left(\frac{C F_{i t}}{K_{i, t-1}}\right)+\pi L O G A S S E T_{i, t}+\rho L E V E R A G E_{i, t}+\omega G R O U P_{i t} \\
+\sigma\left(\text { GROUP }_{i t} \times \text { TIMETREND }\right)
\end{gathered}
$$

then we get back [6]. Thus, we can justify the use of [6] starting from a frontier model. The advantage of using [7] is that the distributional assumptions about $u$ and $v$ in the stochastic frontier model guarantees that $-E\left(u_{i t}\right)<0$, thereby shedding light on the extent of financial constraint of a firm in each of the years of analysis. As discussed earlier in this section, the traditional approaches based on OLS and fixed effects panel models do not offer this advantage.

Finally, the stochastic frontier approach allows us to estimate the marginal impact of each (continuous) $Z$ variable on the degree of financial constraint, at different points of the distribution. This can provide important insights. For example, if we find that the impact of size (i.e., LOGASSETS) on the degree of financial constraints is large for firms that are below the $50^{\text {th }}$ percentiles of the size distribution, but small or not economically meaningful thereafter, we would be able to infer that while size can ameliorate financial constraints, it does not play an important role in reducing financial constraint beyond a point, and hence 
larger firms should look at alternative factors such as leverage to reduce financial constraints. Since the stylized methodology based on the use of OLS and panel regression models do not permit us to estimate the impact of firm characteristics on the degree of financial constraints itself, they cannot, of course, provide such insight. ${ }^{10}$

\section{Applying the stochastic frontier approach: data and empirical strategy}

We apply the stochastic frontier model described in [3] - [5] above to firm-level data from the Indian manufacturing sector, for the 1997-2006 period. ${ }^{11}$ India, which has a bank-based financial system, has witnessed progressive liberalisation of its real sector since 1985 and its financial sector since 1992. By the second half of the 1990s, the banks enjoyed a fair degree of autonomy (Bhaumik and Piesse, 2008), and the equity market was growing rapidly. Correspondingly, the post-1991 period witnessed significant growth in both credit and private sector investment. ${ }^{12}$ The net outstanding credit to the industrial sector rose from INR 578.6

${ }^{10}$ Indeed, estimating [1] or [2] for each quintile of the size distribution would indicate, through the cash flow variable, whether or not larger firms are less financially constrained than the smaller firms. But we would not have a sense of the extent to which (say) a $\$ 1$ million increase in assets reduces financial constraint.

${ }^{11}$ We do not include data for 2007-09 in our sample to exclude the period of global financial crisis from our sample. While India was not significantly affected by the crisis, there was, nevertheless, a noticeable drop in the country's GDP growth rate, implying a possible change in its business environment.

${ }^{12}$ Resources mobilised through capital market continue to account for less than 3 percent of GDP. By contrast, domestic credit provided by the banking sector rose from 44.1 percent of 
billion in 1993-94 to INR 3408.9 billion in 2008-09, in real terms, recording an annual average growth rate of 11 percent. However, because of the implementation of stricter prudential norms banks have held government securities over and above the prescribed minimum requirement. This has resulted in lower credit growth than what would have been consistent with the high rate of growth in the real sector (Marjit and Das, 2008). The average annual growth rate of private investment for (roughly) the corresponding period was 17.77 percent. Yet, even during the second half of the last decade, there was prima facie evidence of financial constraints inhibiting investment growth at the firm level (Chaudhuri, Koudal and Sheshadri, 2009). The country therefore provides an excellent setting for an empirical examination of the factors that affect firm-level investment in the presence of capital/credit market imperfections and agency conflicts.

Our sample includes a set of 598 Indian private manufacturing firms incorporated prior to 1991. We focus on private firms which, unlike many state-owned firms, do not have soft budget constraints on account of access to the public purse, and, even though some of the firms have foreign equity participation, they do not have access to the global capital market. Our sample of firms are largely dependent on the local credit market to finance their investments which is quite representative for not just Indian firms but privately owned firms in nearly all emerging markets. The choice of firms that were incorporated before 1991 ensures that all the firms in the same had time to develop banking relationships well before the sample period of 1997-2006. Our results should therefore not be influenced by a subsample of new firms that are credit constrained on account of weak banking relationships. Finally, the choice of manufacturing firms alone is consistent with a wide range of empirical

GDP in 1995 to 64.2 percent of GDP in 2007. By all accounts, India remains a bank based economy. 
analyses that do not pool together manufacturing and services sector firms that are different in many ways.

Data on these firms are obtained from the widely used Prowess database marketed by the Centre for Monitoring the Indian Economy (CMIE). Prowess provides balance sheets and profit and loss accounts of firms in a standardised format, making the numbers comparable across the firms. Data on variables such as sales, capital, investments and cash flows can therefore be directly obtained from the database or easily computed. Prowess also provides information on financial ratios such as the debt-to-equity ratio that is our measure of leverage or financial fragility, as well as information on business group affiliations Our definition of variables is consistent with the existing literature.

[insert Table 1 about here]

In Table 1, we report the summary statistics of the variables we use in our regression models. The figures are self-explanatory, and only one variable needs further explanation. We discovered through experimentation that the debt-to-equity ratio of firms, our measure of leverage, does not have an impact on investment decisions or the aforesaid inefficiency when it is used in the relevant regression specification in linear and quadratic forms. This is not surprising; a change in the leverage from (say) 0.2 to 0.3 may not have any impact on a firm's ability to borrow, but an increase from 1.6 to 1.7 might have a significant impact. ${ }^{13}$ Indeed

\footnotetext{
${ }^{13}$ This argument is not unique to this particular context. For example, while an increase in an investor's ownership from 10 percent of a company to 11 percent may not have any impact on the behaviour or performance of the company, an increase from 49 percent to 50 percent, which gives the investor outright control of the company, may have a significant impact.
} 
evidence suggests that leverage has a threshold effect on credit ratings. Hence, as a proxy for leverage, we used a dummy variable that takes the value one when the leverage is high, and zero otherwise. Experimentation with the threshold suggests that leverage adds to financial constraint for threshold values of debt-to-equity ratio beyond 1.6. When the threshold of 1.6 is used, the coefficient of the high-leverage dummy variable is significant at the 10 percent level. The statistical significance of the coefficient improves as the threshold is raised. We use the cut-off value of 1.8 for our estimation. In our sample, sixteen percent of the firms reported high leverage.

Our empirical strategy is in two parts. To begin with, we demonstrate that the interpretations of the $Z$ variables in the stochastic frontier model are consistent with those of the coefficients of these variables in OLS and panel regression models. Our expectations are summarised in the following table:

\begin{tabular}{lccc}
\hline & Pooled OLS & Panel & Stochastic \\
& & fixed effects & frontier \\
\hline Cash flows & + & + & - \\
$($ Log) assets & + & + & - \\
Leverage & - & - & + \\
Business group & + & + & - \\
membership & & & $?$ \\
Business group & & $?$ & \\
membership $\times$ Time trend & $?$ & & \\
\end{tabular}


For example, we know from the stylized literature that existence of financial constraints is manifested by a positive (and significant) coefficient of the cash flow variable. In the stochastic frontier model, however, the cash flow variable does not explain investment itself, rather investment inefficiency or the degree of financial constraints. Hence, if cash flows alleviate financial constraints, i.e., reduce investment inefficiency, then in the stochastic frontier model the cash flow variable will have a negative coefficient. The rest of the table can be similarly explained. After confirming that the coefficient estimates of the $Z$ variables are meaningful, we demonstrate and discuss the aforementioned advantages of the stochastic frontier approach.

\section{Regression results and discussion}

The regression results are reported in Tables 2 and 3. In Table 2, we report the OLS estimates and estimates of the panel fixed effects model. For each of these models, we progressively introduce the factors that determine investment in contexts without agency conflicts and market imperfections (Columns 1 and 4), the much discussed cash flow and (log) asset variables that capture a firm's ability to mitigate credit constraints (Columns 2 and 5), and the less discussed leverage and business group membership variables that also affect a firm's investment decisions (Columns 3 and 6). The F-statistics and the R-squared values for the models are reported as well, and they indicate that the specifications are meaningful, and are a reasonably good fit for the data.

[insert Table 2 about here] 
In Table 3, we report the estimates of stochastic frontier models with fixed effects. The model in column (1) assumes that investment inefficiency $u$ is i.i.d., $N\left(0, \sigma_{u}^{2}\right), u_{i t} \geq 0$ but does not attempt to explain this inefficiency. The models in columns (2) and (3) capture the impact of firm characteristics on inefficiency. As in the case of the OLS and fixed effects panel models, we introduce the firm characteristics gradually. We include the cash flow and (log) assets variables in column (2), and add the leverage and business group membership variables in column (3).

[insert Table 3 about here]

The regression results suggest that, as expected, Tobin's $q$ and investment decisions are generally positively correlated. Current sales too always has a positive impact on investment, while sales lagged one period has a positive coefficient for the panel fixed effect model and most of the specifications of the stochastic model, but negative coefficients for the OLS models. As we have already noted, when sales accelerator is modelled as a function of current and past sales, some of the coefficients may be negative (Abel and Blanchard, 1989). Overall, wherever the sales lagged one period has a negative coefficient, the coefficient of the current sales variable is much larger, and it is reasonable to conclude that sales have a positive impact on investment decisions.

We now turn to the factors that alleviate or aggravate the friction in the capital and credit markets. The coefficients of these variables, reported in Tables 2 and 3, can be summarised as follows:

Panel

Pooled OLS

Stochastic frontier

fixed effects 


\begin{tabular}{lccc}
\hline Cash flows & & + & - \\
$($ Log) assets & + & + & + \\
Leverage & - & - & - \\
Business group & + & & \\
membership & & & + \\
Business group & - & - & \\
membership $\times$ Time trend & & & \\
\hline
\end{tabular}

In other words, the coefficient estimates of the $Z$ variables in the stochastic frontier model, which are remarkably robust across estimation methodologies and specifications, are consistent with their interpretation in the stylized literature, and hence meaningful. ${ }^{14}$ Overall, the regression estimates suggest the following:

${ }^{14}$ We undertake four robustness checks for our estimations. First, we recognize the fact that in India long term debt often accounts for a greater proportion of assets than equity. This is especially true for older firms, a lot of whose assets were acquired prior to the growth of the Indian equity market. Following Fazzari, Hubbard and Petersen (1988), we replace the usual measure of Tobin's $q$ with one that takes into account long term debt, i.e., our new measure of Tobin's $q$ is the ratio of the sum of the value of equity and long term debt to the replacement cost of these assets. Second, we take into account the possibility that, aside from Tobin's $q$ and expected sales, investment decisions can be affected by uncertainty. We use as our proxy for a firm's uncertainty during a given year the variance of stock returns of that firm during that year (Leahy and Whited, 1996). Third, following the suggestion of an anonymous referee, we replaced the dummy variable for high leverage with a more general functional form with respect to leverage, namely, $\alpha_{1} L+\alpha_{2}\left(L-L^{*}\right) D$, where $L$ is leverage, $L^{*}$ 
- Investment is positively correlated with cash flow; conversely, cash flow reduces financial constraints. This is consistent with the mainstream literature on firm level investments.

- Similarly, investment (financial constraint) is positively (negatively) correlated with (log) assets, our proxy for access to collateral. This has significant implications for fast growing firms and service sector firms whose collaterizable assets may be small relative to their investment needs.

- The extent of friction or financial constraint is higher for highly leveraged firms, signalling perhaps both prudence and risk aversion of the creditors and investors. This is consistent with the available evidence about the risk aversion of Indian banks (Bhaumik and Piesse, 2008).

- The pooled OLS and stochastic frontier estimates suggest that business group membership alleviates credit constraints, which is consistent with the stylised view about internal capital markets associated with these organisational structures. But the negative coefficient of the interaction term involving the time trend indicates that the advantages of belonging to a business group declines over time and disappears by the ninth or tenth year of the sample period, by the end of the first decade of this century. The panel fixed effects results suggest that business group membership aggravated is the threshold for high leverage (such as 1.8 ), and $D$ is a dummy variable that takes the value 1 when $L>L^{*}$. We experiment with more than one value for $L^{*}$. Finally, we replace the debt-to-equity ratio by another measure of financial distress, namely, the solvency ratio. The choice of solvency ratio as a proxy for financial fragility is consistent with the research of Gryglewicz (2011). However, none of these changes affects our results. We, therefore, do not report the coefficient estimates associated with these new specifications. 
credit constraints throughout the sample period. This is consistent with the argument that while business groups are an optimal response to market failures in various contexts, the disadvantages associated with their opaque structures and questionable corporate governance qualities, as well as resistance to change, might outweigh the advantages once economic reforms liberalise factor and product markets and reduce the difficulty in accessing resources. This result is also consistent with that of Borensztein and Lee (2000), who found that subsequent to the financial crisis in South Korea in 1997, the chaebol affiliated firms lost their advantage with respect to access to credit.

[insert Figure 1 about here]

Next, we generate firm- and year-specific measures of technical (investment) efficiency from our stochastic frontier models. To recapitulate, the investment efficiency measure is bounded in $(0,1)$, with values close to zero indicating a high degree of credit constraint and values close to one indicating very little credit constraint. In order to understand how financial liberalisation and associated corporate restructuring have affected credit constraints of Indian firms, in Figure 1 we report the distributions of firm-specific investment efficiency for 1997 and 2006. Figure 1(a) suggests that while larger firms (in the top quartile of size distribution) were less credit constrained than the smaller firms (in the bottom quartile of the size distribution) in 1997 - distribution of investment efficiency of larger firms shifted to the right of the corresponding distribution for smaller firms - by 2006 the difference between the two types of firms had largely disappeared. ${ }^{15}$ Similarly, Figure 1(c) suggests that while highly

\footnotetext{
${ }^{15}$ It is easy to see that we could have taken into account the entire distribution of the degree of credit constraint (reflected by the measure of investment efficiency), without splitting the
} 
indebted firms (those with debt-to-equity ratio higher than 1.8) were more credit constrained than firms with lower level of indebtedness (debt-to-equity ratio less than 1.8) in 1997, any remaining difference is not discernible from the distributions for 2006. However, it is difficult to detect patterns from Figure 1(b) which graphs the investment efficiency of business group members and non-members.

[insert Table 4 about here]

In Table 4, we report the means and medians of the distributions plotted in Figures 1-3. It is easily seen that the contrast between investment efficiency of larger and smaller firms, and firms with and without a high level of indebtedness was sharper in 1997 than in 2006. By 2006, characteristics such as size and leverage were no longer sufficient to characterise the extent of credit constraints experienced by the firms; the differences in means and medians of the size and leverage classes was negligible. As such, this would suggest that credit market imperfections were reduced by 2006; firms did not require credible signals in the form of assets and low leverage to access credit. At the same time, however, the mean and median investment efficiency of all types of firms were reduced between 1997 and 2006. A plausible explanation for this is that firm-level demand for credit was rising faster than access to credit, as the fast growing economy opened up ever more opportunities for the firms. This explanation is consistent with the findings of Banerjee et al. (2005), namely, that banks in India determine credit in period $t$ based on credit sanctioned in period $t$ - 1 , without taking into

sample in any way, and constructed a matrix with size deciles along one axis and investment efficiency deciles along the other. The off-diagonal elements of this matrix would have told us whether the degree of financial constraint is biased in favour of large or small firms. 
consideration the growth potential of the firms. It is also consistent with the findings of Marjit and Das (2008).

The summary measures of investment efficiency reported in Table 4 also have implications for corporate restructuring. Business group non-members had higher median (and mean) investment efficiency than their business group member counterparts in 1997, and by 2006 the difference in the median investment efficiency of business group members and nonmembers had widened further. To recapitulate, the marginal impact of business group membership on investment efficiency (inefficiency) was positive (negative) at the start of the sample period, but this marginal impact had turned negative (positive) by 2006. The mean/median investment efficiency figures reported here suggest that even as business group membership itself aggravated financial constraints for member firms between 1997 and 2006, other characteristics of business group affiliated firms did not change in a way that could offset this disadvantage. In other words, while business groups persist in the Indian corporate landscape, as in countries like South Korea (Boresnztein and Lee, 2000), the rationale for forming business groups and sustaining corporate structures that incorporate them has weakened since the initiation of financial and other reforms in the early nineties. This consistency with the literature is a reaffirmation of the meaningfulness of our measure of degree of financial constraint.

[insert Table 5 about here]

Finally, we estimate the marginal impact of the continuous variables, namely, cash flow and $(\log )$ assets, on the degree of financial constraint, for the $10^{\text {th }}, 25^{\text {th }}, 50^{\text {th }}, 75^{\text {th }}$ and $90^{\text {th }}$ percentiles of their respective distributions. The marginal effects suggest that while cash flow 
and $(\log )$ assets reduce investment inefficiency, i.e., alleviate financial constraints for firms at all points of their distributions, the marginal impact of both these variables is much higher for firms that are at the lower tails of these distributions. For example, cash flow has a marginal effect of -0.0016 for firms at the $90^{\text {th }}$ percentile of the distribution, but this marginal effect doubles to -0.0032 for firms that are at the $10^{\text {th }}$ percentile of the distribution. Similarly, the marginal effects of (log) assets for the corresponding percentile levels of its distribution are 0.1062 and -0.2104 , respectively.

In sum, the estimates of our stochastic frontier model are both consistent with the stylized literature that uses OLS and panel regression models, and have meaningful interpretations. We also successfully demonstrate the three advantages of the stochastic frontier approach over the stylized methodology, all of which stem from our ability to estimate the degree of financial constraint of each firm and for each time period.

\section{Conclusions}

In this paper, we argue that the stochastic frontier approach has significant advantages over the empirical methodology that is used in the stylized literature on financial constraint of firms. The former provides much better insights about the degree of financial constraints of firms and its change over time, and also about the impact of individual firm characteristics on this degree. We demonstrate these advantages by applying the stochastic frontier approach to a firm level data set from India, for the 1997-2006 period.

Our results suggest that firms in India experience significant credit constraint despite significant banking expansion since 1969 and despite nearly two decades of financial 
liberalization. There is a decline in median investment efficiency of the firms over the sample period, when investment efficiency refers to the ability a firm to translate characteristics such as its Tobin's $q$ ratio and sales-to-capital ratio into actual investment. In keeping with the existing literature in firm-level investments, financial constraints in India are alleviated by cash flows and (log) assets of firms, and aggravated by a high leverage level. We also find that business groups alleviate credit constraints for member firms, but their ability to do so has declined over time.

The stochastic frontier approach provides us with a powerful tool to explore the issue of financial constraint that has gained in importance since the financial crisis of 2008-09. Wider adoption of this tool would therefore be an important step in the direction of improved analyses of these constraints.

\section{Acknowledgement}

The authors would like to thank an anonymous referee for helpful comments and advice, and the British Academy for financial support for procuring the Prowess data archive (Grant no.: SG-54061). Das also acknowledges ESRC for its grant (No. RES-072-27-0025) for a visiting fellowship at Essex Business School, Essex University, UK, when the study began. Authors remain responsible for all remaining errors. 


\section{References}

Abel, A., 1980. Empirical investment equations: An integrative approach, CarnegieRochester Conference Series on Public Policy 12, 39-91.

Abel, A., Blanchard, O., 1989. Investment and sales: Some empirical evidence, Working paper no. 2050, National Bureau of Economic Research, Cambridge, Massachusetts.

Aivazian, V.A., Ge, Y., Qiu, J., 2005. The impact of leverage on firm investment: Canadian evidence. Journal of Corporate Finance 11, 277-291.

Audretsch, D.B., Elston, J.A., 2002. Does firm size matter? Evidence on the impact of liquidity constraints on firm investment behaviour in Germany. International Journal of Industrial Organization 20, 1-17.

Banerjee, A., Cole, S., Duflo, E., 2005. Bank financing in India. In: Tseng, W. and Cowen, D. (Eds). India's and China's Recent Experience with Reform and Growth, Palgrave Macmillan: New York.

Beck, T., Demirguc-Kunt, A., 2006. Small and medium-size enterprises: Access to finance as a growth constraint, Journal of Banking and Finance 30, 2931-2943.

Bhaumik, S.K., Piesse, J., 2008. Does lending behaviour of banks in emerging economies vary by ownership? Evidence from the Indian banking sector. Economic Systems 32, 177 196. 
Bond, S., Meghir, C., 1994. Dynamic investment models and the firm's financial policy. Review of Economic Studies 61, 197-222.

Borensztein, E., Lee, J-W., 2000. Financial crisis and credit crunch in Korea: Evidence from firm level data. Working paper no. WP/00/05, International Monetary Fund, Washington, D.C.

Chaudhuri, A., Koudal, P., Seshadri, S., 2009. Demystifying investment growth in Indian industries. Mimeo, Deloitte, Downloadable from http://www.deloitte.com/assets/DcomGlobal/Local\%20Assets/Documents/dtt_sensex_part1\%282\%29.pdf.

Fazzari, S.M., Hubbard, R.G., Petersen, B.C., 1988. Financing constraints and corporate investment. Brookings Papers on Economic Activity, Vol. 1, pp. 141-206.

Fazzari, S.M., Petersen, B.C., 1993. Working capital and fixed investment: New evidence on financing constraints. RAND Journal of Economics 24, 328-341.

Gelos, R.G., Werner, A.M., 2002. Financial liberalization, credit constraints, and collateral: Investment in the Mexican manufacturing sector. Journal of Development Economics 67, 127.

Gryglewicz, S., 2011. A theory of corporate financial decisions with liquidity and solvency concerns. Journal of Financial Economics 99, 365-384. 
Guncavdi, O., Bleaney, M., McKay. A., 1998. Financial liberalization and private investment: Evidence from Turkey. Journal of Development Economics 57, 443-455.

Hayashi, F., 1982. Tobin's marginal-Q and average-Q: A neoclassical interpretation. Econometrica 50, 213-224.

Hoshi, T., Kashyap, A.K., Scharfstein, D., 1991. Corporate structure, liquidity and investment: Evidence from Japanese industrial groups. Quarterly Journal of Economics 106, $33-60$.

Hubbard, R.G., 1998. Capital market imperfections and investment. Journal of Economic Literature 36, 193-225.

Kadapakkam, P-R., Kumar, P.C., Riddick, L.A., 1998. The impact of cash flows and firm size on investment: The international evidence. Journal of Banking and Finance 22, 293-320.

Kaplan, S.N., Zingales, L., 1997. Do financial constraints explain why investment is correlated with cash flow? Quarterly Journal of Economics 112, 169-215.

Kumbhakar, S.C., Lovell, C.K.A., 2000. Stochastic frontier analysis, Cambridge University Press.

Laeven, L., 2003. Does financial liberalization reduce financial constraints. Mimeo, Downloadable from 
http://www.luclaeven.com/papers_files/2003\%20Laeven\%20Financial\%20liberalization\%20 FM.pdf.

Lang, L.E., Ofek, E., Stulz, R., 1996. Leverage, investment and firm growth. Journal of Financial Economics 40, 3-29.

Leahy, J., Whited, T., 1996. The effect of uncertainty on investment: some stylized facts. Journal of Money, Credit, and Banking 28, 64-83.

Marjit, S., Das, P.K., 2008. Financial sector reforms for stimulating investment and economic growth - The Indian experience. In: Asian Development Bank (Ed.), Macroeconomic Management and Government Finances, Oxford University Press: New Delhi.

Pindyck, R.S., 1991. Irreversibility, uncertainty, and investment. Journal of Economic Literature 29: 1110-1148.

Shen, C.-H., Wang, C.-A., 2005. Does bank relationship matter for a firm's investment and financial constraints: The case of Taiwan. Pacific-Basin Finance Journal 13, 163-184.

Shin, H-H., Park, Y.S., 1999. Financing constraints and internal capital markets: Evidence from Korean 'chaebols'. Journal of Corporate Finance 5, 169-191.

Stiglitz, J.E., Weiss, A.M., 1981. Credit rationing in markets with imperfect information. American Economic Review 71, 393-410. 
Wang, H-J., 2003. A stochastic frontier analysis of financing constraints on investment: The case of financial liberalization in Taiwan. Journal of Business and Economic Statistics 21, 406-419.

Yoshikawa, H., 1980. On the "q" theory of investment. American Economic Review 70, 739743. 
Table 1. Summary statistics

\begin{tabular}{l|cc}
\hline & Mean & $\begin{array}{c}\text { Standard } \\
\text { Deviation }\end{array}$ \\
\hline (Log) Tobin's q & -1.06 & 1.43 \\
$(\log )$ Sales(t)/Capital(t-1) & 0.31 & 0.90 \\
$(\log )$ Sales(t-1)/Capital(t-2) & 0.36 & 0.82 \\
Cash flow(t)/Capital(t-1) & 2.25 & 2.21 \\
$(\log )$ Assets & 4.14 & 1.58 \\
Proportion of firms with high debt-to-equity ratio & 0.16 & 0.36 \\
Proportion of firms with business group membership & 0.31 & 0.46 \\
\hline
\end{tabular}


Table 2. Stylized regression models

\begin{tabular}{|c|c|c|c|c|c|c|}
\hline & \multicolumn{3}{|c|}{ Ordinary least squares } & \multicolumn{3}{|c|}{ Panel fixed effects } \\
\hline & {$[1]$} & [2] & [3] & [4] & [5] & [6] \\
\hline (Log) Tobin's q & $\begin{array}{l}0.11 * * * \\
(0.02)\end{array}$ & $\begin{array}{l}0.11 * * * \\
(0.02)\end{array}$ & $\begin{array}{l}0.04 * * \\
(0.02)\end{array}$ & $\begin{array}{l}0.13 * * * \\
(0.02)\end{array}$ & $\begin{array}{l}0.17 * * * \\
(0.02)\end{array}$ & $\begin{array}{l}0.12 * * * \\
(0.02)\end{array}$ \\
\hline$(\log ) \operatorname{Sales}(\mathrm{t}) / \mathrm{Capital}(\mathrm{t}-1)$ & $\begin{array}{l}0.71 * * * \\
(0.05)\end{array}$ & $\begin{array}{l}0.67 * * * \\
(0.04)\end{array}$ & $\begin{array}{l}0.67 * * * \\
(0.03)\end{array}$ & $\begin{array}{l}0.95 * * * \\
(0.03)\end{array}$ & $\begin{array}{l}0.46 * * * \\
(0.05)\end{array}$ & $\begin{array}{l}0.44 * * * \\
(0.05)\end{array}$ \\
\hline (Log) Sales(t-1)/Capital(t-2) & $\begin{array}{c}-0.20 * * * \\
(0.06)\end{array}$ & $\begin{array}{c}-0.11 * \\
(0.06)\end{array}$ & $\begin{array}{c}-0.17 * * * \\
(0.04)\end{array}$ & $\begin{array}{l}0.35 * * * \\
(0.05)\end{array}$ & $\begin{array}{l}0.54 * * * \\
(0.05)\end{array}$ & $\begin{array}{l}0.55 * * * \\
(0.05)\end{array}$ \\
\hline Cash flow(t)/Capital(t-1) & & $\begin{array}{l}0.005 \\
(0.02)\end{array}$ & $\begin{array}{l}0.01 \\
(0.02)\end{array}$ & & $\begin{array}{l}0.10 * * * \\
(0.02)\end{array}$ & $\begin{array}{c}-0.11 * * * \\
(0.02)\end{array}$ \\
\hline$(\log )$ Assets & & $\begin{array}{l}0.18 * * * \\
(0.02)\end{array}$ & $\begin{array}{l}0.17 * * * \\
(0.01)\end{array}$ & & $\begin{array}{l}0.69 * * * \\
(0.04)\end{array}$ & $\begin{array}{l}0.74 * * * \\
(0.04)\end{array}$ \\
\hline High debt-to-equity ratio & & & $\begin{array}{c}-0.30 * * * \\
(0.07)\end{array}$ & & & $\begin{array}{c}-0.29 * * * \\
(0.06)\end{array}$ \\
\hline Business group membership & & & $\begin{array}{l}0.76 * * * \\
(0.14)\end{array}$ & & & $\begin{array}{l}0.23 \\
(0.82)\end{array}$ \\
\hline $\begin{array}{l}\text { Time trend } \times \text { Business group } \\
\text { membership }\end{array}$ & & & $\begin{aligned}-0.07 * * * \\
(0.01)\end{aligned}$ & & & $\begin{aligned}-0.07 * * * \\
(0.01)\end{aligned}$ \\
\hline Constant & $\begin{array}{l}-3.08 * * * \\
(0.04)\end{array}$ & $\begin{array}{l}-3.88 * * * \\
(0.09)\end{array}$ & $\begin{array}{c}-3.82 * * * \\
(0.09)\end{array}$ & $\begin{array}{l}-3.28 * * * \\
(0.03)\end{array}$ & $\begin{array}{l}-6.25 * * * \\
(0.19)\end{array}$ & $\begin{array}{l}-6.32 * * * \\
(0.32)\end{array}$ \\
\hline F-statistic & $139.42 * * *$ & $114.26 * * *$ & $71.62 * * *$ & $393.67 * * *$ & $302.88 * * *$ & $195.98 * * *$ \\
\hline R-squared & 0.17 & 0.21 & 0.19 & 0.15 & 0.17 & 0.13 \\
\hline Number of firms & 597 & 597 & 586 & 597 & 597 & 586 \\
\hline Number of observations & 4850 & 4850 & 4545 & 4850 & 4850 & 4545 \\
\hline
\end{tabular}


Table 3. Stochastic frontier model

\begin{tabular}{|c|c|c|c|}
\hline & [1] & {$[2]$} & [3] \\
\hline \multicolumn{4}{|l|}{ Frontier equation } \\
\hline (Log) Tobin's q & $\begin{array}{l}0.11 * * * \\
(0.02)\end{array}$ & $\begin{array}{l}0.11 * * * \\
(0.01)\end{array}$ & $\begin{array}{l}0.06 * * * \\
(0.01)\end{array}$ \\
\hline$(\log )$ Sales $(\mathrm{t}) /$ Capital(t-1) & $\begin{array}{l}0.77 * * * \\
(0.03)\end{array}$ & $\begin{array}{l}0.81 * * * \\
(0.02)\end{array}$ & $\begin{array}{l}0.93 * * * \\
(0.02)\end{array}$ \\
\hline$(\log )$ Sales(t-1)/Capital(t-2) & $\begin{array}{c}-0.10 * * \\
(0.04)\end{array}$ & $\begin{array}{l}0.34 * * * \\
(0.03)\end{array}$ & $\begin{array}{l}0.38 * * * \\
(0.03)\end{array}$ \\
\hline Constant & $\begin{aligned}- & 2.04 * * * \\
& (0.18)\end{aligned}$ & $\begin{array}{l}-2.49 * * * \\
(0.02)\end{array}$ & $\begin{array}{l}-2.50 * * * \\
(0.02)\end{array}$ \\
\hline \multicolumn{4}{|l|}{ Inefficiency equation } \\
\hline Cash flow(t)/Capital(t-1) & & $\begin{aligned}- & 0.27 * * * \\
& (0.06)\end{aligned}$ & $\begin{array}{c}-0.10 * * * \\
(0.03)\end{array}$ \\
\hline (Log) Assets & & $\begin{array}{l}-0.07 * * \\
(0.04)\end{array}$ & $\begin{array}{c}-0.07 * * \\
(0.03)\end{array}$ \\
\hline High debt-to-equity ratio & & & $\begin{array}{l}0.21 * \\
(0.13)\end{array}$ \\
\hline Business group membership & & & $\begin{array}{c}-0.62 * * \\
(0.30)\end{array}$ \\
\hline $\begin{array}{l}\text { Time trend } \times \text { Business group } \\
\text { membership }\end{array}$ & & & $\begin{array}{l}0.07 * * * \\
(0.03)\end{array}$ \\
\hline Constant & & $\begin{array}{l}0.80 * * * \\
(0.18)\end{array}$ & $\begin{array}{l}0.58 * * * \\
(0.18)\end{array}$ \\
\hline Number of firms & 597 & 597 & 586 \\
\hline Number of observations & 4850 & 4850 & 4545 \\
\hline
\end{tabular}


Figure 1. Impact of firm characteristics on financial constraint

(a) Size
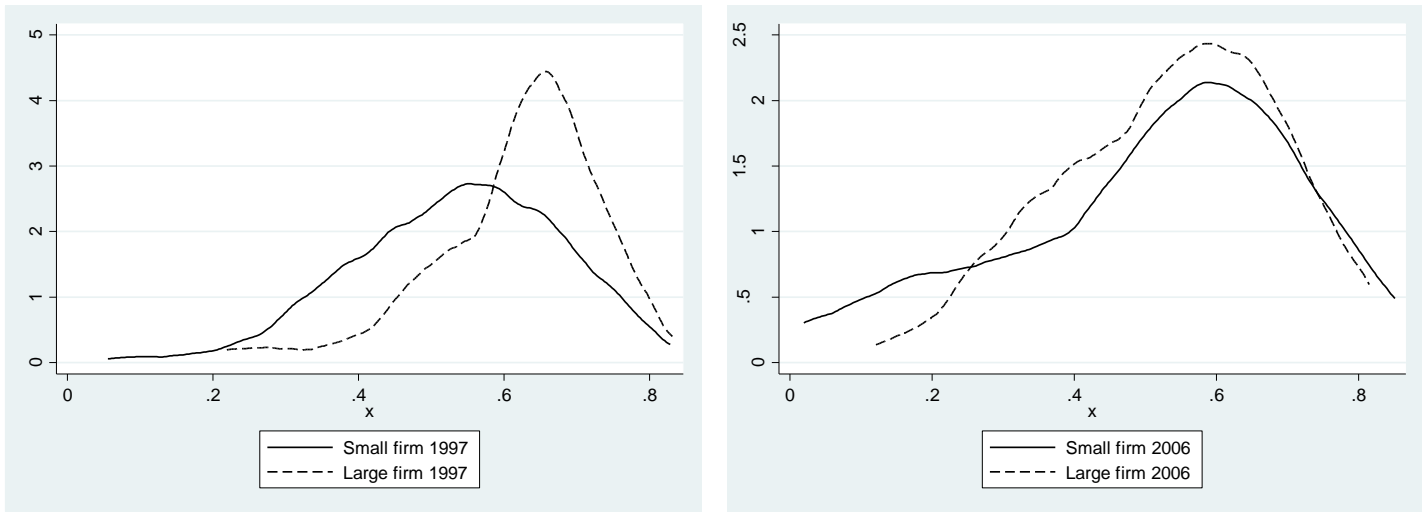

(b) Business group affiliation
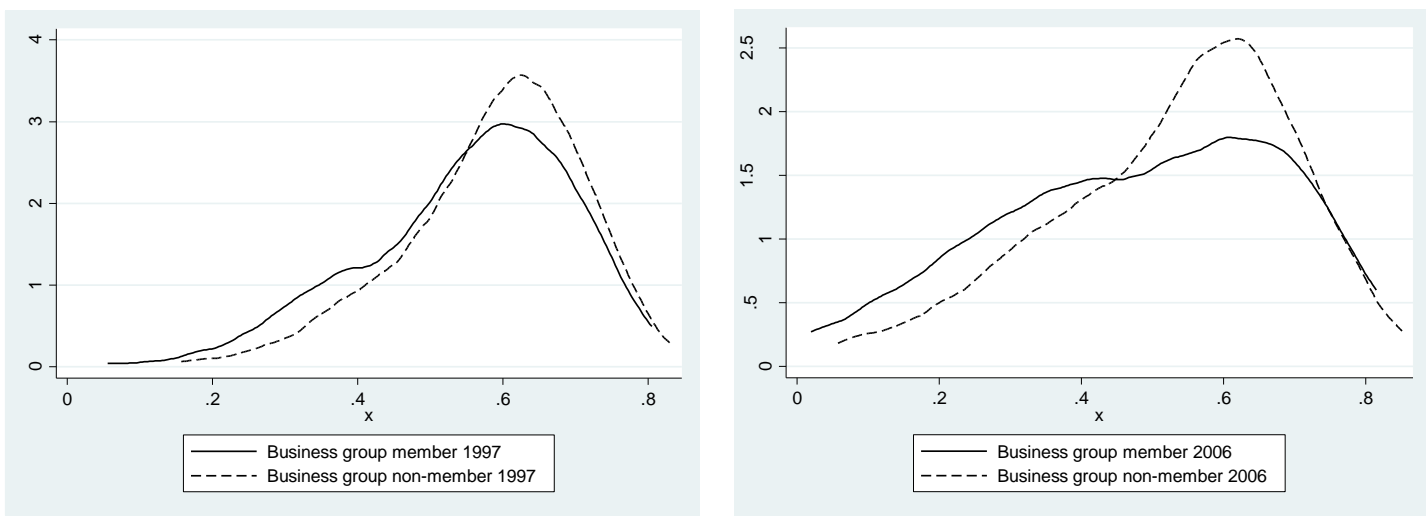

(c) Indebtedness
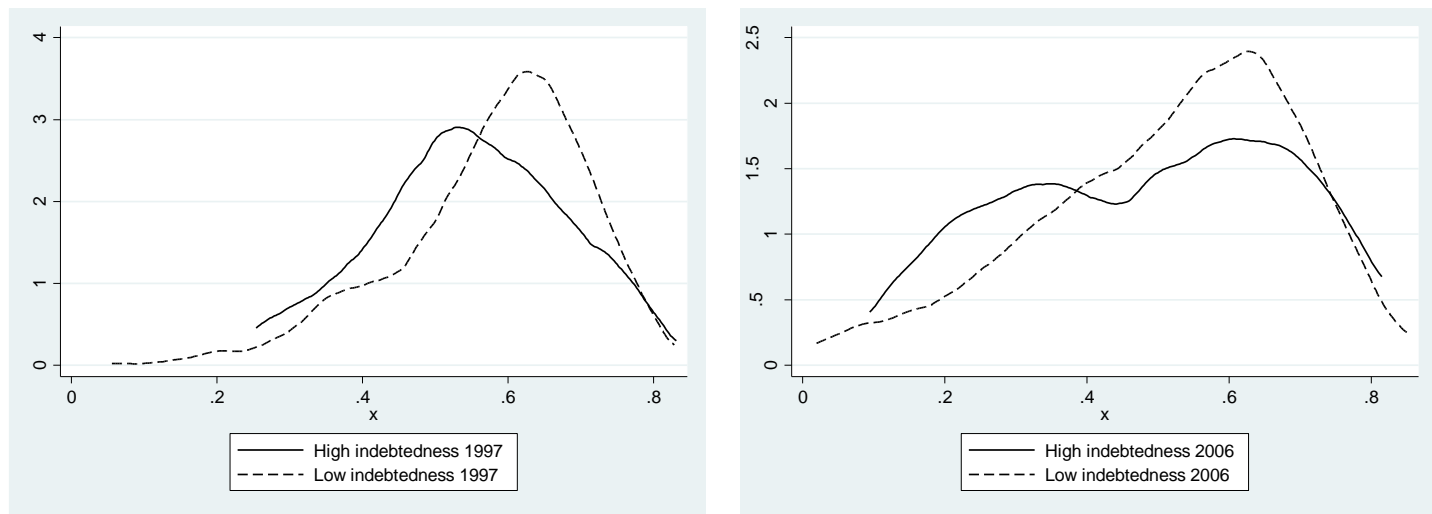
Table 4. Summary statistics for distribution of investment efficiency

\begin{tabular}{|c|c|c|c|c|}
\hline & \multicolumn{2}{|c|}{1997} & \multicolumn{2}{|c|}{2006} \\
\hline & $\begin{array}{c}\text { Mean } \\
\text { (Std. dev.) }\end{array}$ & Median & $\begin{array}{c}\text { Mean } \\
\text { (Std. dev.) }\end{array}$ & Median \\
\hline \multicolumn{5}{|l|}{ Firm size } \\
\hline Smaller & $\begin{array}{c}0.54 \\
(0.14)\end{array}$ & 0.54 & $\begin{array}{c}0.50 \\
(0.20)\end{array}$ & 0.56 \\
\hline Larger & $\begin{array}{c}0.62 \\
(0.11)\end{array}$ & 0.64 & $\begin{array}{c}0.53 \\
(0.15)\end{array}$ & 0.55 \\
\hline $\begin{array}{l}\text { Business group } \\
\text { affiliation }\end{array}$ & & & & \\
\hline Affiliated & $\begin{array}{c}0.55 \\
(0.14)\end{array}$ & 0.55 & $\begin{array}{c}0.48 \\
(0.20)\end{array}$ & 0.49 \\
\hline $\begin{array}{l}\text { Unaffiliated } \\
\text { Indebtedness }\end{array}$ & $\begin{array}{c}0.59 \\
(0.12)\end{array}$ & 0.59 & $\begin{array}{c}0.52 \\
(0.17)\end{array}$ & 0.56 \\
\hline High & $\begin{array}{c}0.55 \\
(0.13)\end{array}$ & 0.55 & $\begin{array}{c}0.48 \\
(0.19)\end{array}$ & 0.52 \\
\hline Not high & $\begin{array}{c}0.58 \\
(0.13)\end{array}$ & 0.60 & $\begin{array}{c}0.51 \\
(0.17)\end{array}$ & 0.55 \\
\hline
\end{tabular}

Note: Values within parentheses are standard deviations. 
Table 4. Marginal effects of $Z$ variables

\begin{tabular}{l|cc}
\hline & \multicolumn{2}{|c}{$(Z)$ variables explaining } \\
& \multicolumn{2}{|c}{ inefficiency } \\
& Cash flow & (Log) assets \\
\hline $10^{\text {th }}$ percentile & -0.0032 & -0.2104 \\
$25^{\text {th }}$ percentile & -0.0027 & -0.1771 \\
$50^{\text {th }}$ percentile & -0.0022 & -0.1488 \\
$75^{\text {th }}$ percentile & -0.0018 & -0.1243 \\
$90^{\text {th }}$ percentile & -0.0016 & -0.1062 \\
\hline
\end{tabular}

